\title{
Aufsätze/Essays
}

\section{Apollinaris of Laodicea in the Catenae as a Source of Hexaplaric Readings ${ }^{1}$}

\author{
Reinhart Ceulemans
}

Katholieke Universiteit Leuven, Institute for Early Christian and Byzantine Studies, BlijdeInkomststraat 21 bus 3318, BE-3000 Leuven, Email: Reinhart.Ceulemans@arts.kuleuven.be

\section{Introduction}

Patristic references in contemporary scholarly studies on Apollinaris of Laodicea tend to focus on the dogmatic and Christological contents of this author's oeuvre rather than on his abilities as a textual critic of the Greek Old Testament. Nonetheless, having adhered to the Antiochene exegetical methods, Apollinaris (ca. 315-391) was very well aware of the differences between the various Greek Bible versions that were available to him. In this regard, he occasionally cited the versions of $\alpha^{\prime}, \sigma^{\prime}$ and $\theta^{\prime}$. This particular aspect of his scholarly activities has only received little attention. Consequently, some of the evidence he offered has been ignored by modern editors of Hexaplaric fragments.

Of Apollinaris' bulky oeuvre, only little has survived. This is due not only to the normal problems that are typical to the transmission of ancient writings, but also to the early damnation Apollinaris and his followers have suffered from (from the year 377 onward). Of his exegetical writings, too, only small fragments have reached us, which hinders a correct assessment of Apollinaris' exegesis and of his biblical text-critical interest, sources and abilities. Nevertheless, writings in which he commented upon Scripture must have been many in number, according to the testimony of Jerome,

1 Preliminary remarks: (1) Bible verses are always identified on the basis of their position in the LXX corpus, not in the Hebrew Bible. (2) If applicable, Greek manuscripts are identified on the basis of the Septuaginta-Unternehmen's reference survey: the abbreviation "Ra" followed by a number refers to the corresponding entries in Alfred Rahlfs, Verzeichnis der griechischen Handschriften des Alten Testaments (Mitteilungen des SeptuagintaUnternehmens der Akademie der Wissenschaften in Göttingen 2; Berlin, 1914) and/ or the updated and expanded redaction by Detlef Fraenkel, Die Überlieferung bis zum VIII. Jahrbundert (Vol. 1,1 of Septuaginta: Vetus Testamentum Graecum Auctoritate Academiae Scientiarum Gottingensis editum Supplementum: Verzeichnis der griechischen Handschriften des Alten Testaments; by A. Rahlfs; Göttingen, 2004). 
who once studied with Apollinaris. ${ }^{2}$ Apollinaris wrote commentaries both on the New and the Old Testament. It is the latter group of commentaries, especially, that seem of interest to the topic at hand, which focuses on Hexaplaric readings. ${ }^{3}$ Indeed, Jerome explicitly mentioned commentaries by Apollinaris on the following Old Testament books: Psalms, Ecclesiastes, Isaiah, Hosea and Malachi. In addition to these books, fragments are ascribed to him in catenae on the Octateuch, Job, Proverbs, Song of Songs, Ezekiel, Daniel, and Jeremiah. ${ }^{4}$

It is only thanks to the catenae, the compilers of which often sacrificed considerations of orthodoxy in favor of content-related selection motives, that some fragments of this condemned Father's exegetical oeuvre have survived. Of course one has to be aware of the limitations one is confronted with when using catena fragments of Apollinaris for reconstructing his exegetical motives: having passed the selection criteria of their Byzantine compilers, the catena fragments do not necessarily offer a representative sample of Apollinaris' commentaries. Therefore the patristic scholar who investigates the exegetical methods of this author is confronted with that awkward feeling catena fragments often bring about: on the one hand, they offer the only data one can work with but on the other hand one realizes the limited results one can draw from them.

The present article, however, does not wish to undertake that kind of patristic research. Its aim is much more basic: it only draws attention to the fact that textual critics of the Greek versions of the Hebrew Bible can gather much interesting data by taking a look at such catena fragments. This has not been done sufficiently in the past. ${ }^{5}$ By looking into some critically edited catenae, ${ }^{6}$ the present author wishes to highlight - once

2 See the references provided by Ekkehard Mühlenberg, "Apollinaris von Laodicea," TRE 3 (Berlin, 1978): (362-371) 365. The overview provided in Henri de Riedmatten, "Le texte des fragments exégétiques d'Apollinaire de Laodicée," Recherches de Science Religieuse 44 (1956): 560-566 is not entirely complete. On Apollinaris' teaching of Jerome, see Pierre Jay, “Jérôme auditeur d'Apollinaire de Laodicée à Antioche," REAug 20 (1974): 36-41.

3 Then again, the present article's fourth section shows that New Testament catenae, too, can be important for retrieving Hexaplaric fragments.

4 See the overview in CPG 3680-3689.

5 This remark is not so much intended as a reproach of the work of previous editors of Hexaplaric fragments, who did not have important tools at their disposal (such as an expanded version of the Thesaurus Linguae Graecae), but rather as a stimulus for future editors, namely to pay enough attention to this corpus.

6 As is well known, attributions of scholia provided in catenae are often incorrect, if existent at all. Critical judgment by the catena's editor is needed in order to decide on the authorship and authenticity of individual fragments transmitted in catenae. For example, in the monophysite catena on Ezekiel, most of the scholia attributed to Apollinaris in fact belong to Theodoret of Cyrrhus. See the remark in CPG 3688 as well as Laurence Vianès, "La chaîne monophysite sur Ézéchiel 36-48: Présentation, texte critique, traduction française, commentaire" (Ph.D. diss., École pratique des hautes études Paris, 1996), 55. Moreover, critical editing showed that all fragments ascribed to Apollinaris in the catenae on Job turn out to belong to Polychronius of Apamea: see Ursula and Dieter 
again $^{7}$ - the importance of the corpus of catenae for finding readings of $\alpha^{\prime}, \sigma^{\prime}$ and $\theta^{\prime}$ and to show that Apollinaris offered more of such readings than present editions of Hexaplaric readings cause to think.

For the present study, three critically edited (corpora of) catenae have been selected: ${ }^{8}$ the catenae on Genesis (which are a part of the corpus of catenae on the Octateuch), edited by Françoise Petit; ${ }^{9}$ the scholia of Apollinaris transmitted in the catenae on Psalms and edited by Ekkehard Mühlenberg; ${ }^{10}$ the fragments of Apollinaris' commentary on Romans transmitted in the catenae on the Pauline Epistles and edited by Karl Staab. ${ }^{11}$ Each of those catenae shows that, in every case due to one particular reason, Apollinaris has not been identified or recognized appropriately as a Hexaplaric source.

\section{Catenae on Genesis: Apollinaris not mentioned as a Hexaplaric source}

An examination of the scholia that are identified by Petit as belonging to Apollinaris (CPG 3680) shows that he certainly knew Hexaplaric readings of Genesis and of Deuteronomy. This cannot be deduced from currently

Hagedorn, eds., Einleitung, Prologe und Epiloge, Fragmente zu Hiob 1,1-8,22 (vol. 1 of Die älteren griechischen Katenen zum Buch Hiob; ed. U. Hagedorn; PTS 40; Berlin, 1994), 106. In order to base its argumentation upon sound data, the present article only takes those fragments into consideration that are assigned to Apollinaris in critically edited catenae. For each of those catenae, the editor's judgment is followed with respect to the attribution of the scholia in question to Apollinaris.

7 See e.g. Gilles Dorival, "L'apport des chaînes exégétiques grecques à une réédition des Hexaples d'Origène (à propos du Psaume 118)," Revue d'Histoire des Textes 4 (1974): 45-74.

8 Of course this does not mean that no other catenae are interesting to look into. For example, Procopius of Gaza's epitome on the Song of Songs (CPG 7431), critically edited by Jean-Marie Auwers (Procopius of Gaza, Epitome in Canticum Canticorum [ed. J.-M. Auwers; CChr.SG; in preparation]), contains seventeen brief scholia of Apollinaris, in which three Hexaplaric readings (and an echo or paraphrase of a fourth one) can be found. On those scholia, see Jean-Marie Auwers, L'interprétation du Cantique des cantiques à travers les chaînes exégétiques grecques: Epitomé de Procope, chaîne de Polychronios, chaîne dite d'Eusèbe, Catena Barberiniana (2 vols.; Diss. présentée pour l'obtention du grade d'Agrégé de l'Enseignement Supérieur; Louvain-la-Neuve, 2007), vol. 2, 375-378. The present author wishes to thank Prof. Auwers for having provided access to his yet unpublished edition.

9 See Françoise Petit, ed., La chaîne sur la Genèse: Edition intégrale (4 vols.; Traditio Exegetica Graeca 1-4; Leuven, 1991-1996). (No fragments of Apollinaris can be found in two other editions by Françoise Petit: Catena Sinaitica [vol. 1 of Catenae Graecae in Genesim et in Exodum; ed. F. Petit; CChr.SG 2; Turnhout, 1977] and Collectio Coisliniana in Genesim [vol. 2 of Catenae Graecae in Genesim et in Exodum; ed. F. Petit; CChr.SG 15; Turnhout, 1986].)

10 Ekkehard Mühlenberg, Psalmenkommentare aus der Katenenüberlieferung (3 vols.; PTS 15, 16, 19; Berlin, 1975-1978).

11 Pauluskommentare aus der Griechischen Kirche: Aus Katenenhandschriften (coll. and ed. K. Staab; Neutestamentliche Abhandlungen 15; Münster, 1933; repr. with a new preface, Münster, 1984). 
available editions of Hexaplaric readings of those books: one has to turn to the catenae themselves. None of Apollinaris' fragments in the catenae on Genesis contain a Hexaplaric reading that is offered nominatim. Nonetheless, two scholia contain an anonymous quotation of such a reading. In both cases, the Hexaplaric reading can be found in the editions of Hexaplaric materials that are available today, but Apollinaris' name is not always mentioned.

Various catena manuscripts on Genesis provide, in their margins or as a gloss, a $\sigma$ ' reading of Gen 2:23.12 Somewhat earlier in the very same manuscripts, one finds a scholion on the same verse that belongs to Apollinaris. In that scholion, he anonymously quoted the $\sigma$ ' reading just mentioned. ${ }^{13}$ The reading was already known to Frederick Field, who did not refer to the marginal note/gloss in these catena manuscripts, but only to the anonymous quotation by Apollinaris. ${ }^{14}$ Oppositely, John W. Wevers in the Hexaplaric apparatus to his Göttingen edition only mentioned the marginal note/gloss in those (and other) manuscripts, ignoring the quotation by Apollinaris. ${ }^{15}$ This is understandable: the Göttingen editor probably did not regard Apollinaris as a source for that particular Hexaplaric reading but rather as a further attestation of a reading that was already known through the marginal scholion/gloss. The fact that Apollinaris had not mentioned the name of $\sigma$ ' probably caused his absence from Göttingen's Hexaplaric apparatus. ${ }^{16}$

In a scholion on Gen 49:13, Apollinaris quoted the text of Deut 33:18, but in a version that is not that of the Septuagint. ${ }^{17}$ Indeed, this reading corresponds to one that is edited by Field as well as Wevers and Quast as

12 Petit, La chaine 1 (see note 9), 210 no. 307.

13 Petit, La chaine 1 (see note 9), 197-198 no. 286. The anonymous $\sigma$ ' reading in the fragment identified as belonging to Apollinaris was already noticed by Robert Devreesse, Les anciens commentateurs grecs de l'Octateuque et des Rois (fragments tires des chaînes) (Studi e Testi 201; Città del Vaticano, 1959), 128 n. 2.

14 Origenis Hexaplorum quae supersunt: Sive Veterum Interpretum Graecorum in totum Vetus Testamentum fragmenta: Post Flaminium Nobilium, Drusium, et Montefalconium, adhibita etiam versione Syro-Hexaplari, concinnavit, emendavit, et multis partibus auxit (ed. F. Field; Oxford, 1875; repr., Hildesheim, 1964), ad loc. The catena manuscript mentioned by Field is Ra 135, which witnesses to both scholia of the Genesis catena mentioned in notes 12 and 13 of this article. (The other manuscript mentioned by him, $\mathrm{Ra} 127$, is no catena manuscript and therefore of no importance to the argument at hand.)

15 John W. Wevers, ed., Genesis (vol. 1 of Septuaginta: Vetus Testamentum Graecum Auctoritate Academiae Litterarum Gottingensis editum; Göttingen, 1974), ad loc. app. 2. Manuscripts Ra 17 and $\mathrm{Ra} 135$ are the catena witnesses in question: both of them contain both scholia mentioned above.

16 In contrast to Jerome (CPL 580), who just like Apollinaris only provided further attestation of the reading that was already known from the catena gloss but who did identify the reading he quoted as that of $\sigma^{\prime}$ and therefore was not left unmentioned by Wevers.

17 Petit, La chaîne 4 (see note 9), 401-402 no. 2190. 
a Hexaplaric one. ${ }^{18}$ Although both Petit (in her discussion of the Genesis scholion of Apollinaris) and Field (in his notes to Deut 33:18) assumed the reading to be that of $\sigma$, Wevers and Quast did not assign it to a particular version. The reason is obvious: the only source they (i.e., Wevers and Quast) mentioned, namely Procopius of Gaza's epitome on the Octateuch (CPG 7430), did not explicitly identify the reading but quoted it as a standard biblical lemma. ${ }^{19}$ When editing the anonymous reading, Field as well as Wevers and Quast only relied upon Procopius: they did not mention Apollinaris. One wonders why: it is true that Apollinaris had not explicitly identified the reading as a Hexaplaric one, but neither had Procopius. It would seem more logical to have included Apollinaris as a witness next to Procopius: he is an older source and a more direct one than Procopius, whose text appears to be an epitome of a catena consisting of various authors.

This discussion of both cases raises an important question: to what extent does the apparatus of a critically edited Hexaplaric reading need to mention (a) source(s) that quote(s) a reading that is already known from (and edited on the basis of) (an)other source(s)? ${ }^{20}$ In the cases discussed

18 Field, Origenis Hexaplorum (see note 14), ad Deut 33:18, and John W. Wevers and Udo Quast, eds., Deuteronomium (vol. 3,2 of Septuaginta: Vetus Testamentum Graecum Auctoritate Academiae Scientiarum Gottingensis editum; 2d ed.; Göttingen, 2006), ad 33:18 app. 2.

19 Admittedly, in Procopius of Gaza, Commentarii in Deuteronomium (PG 87,1: 988), the name of $\sigma^{\prime}$ precedes the citation of Deut 33:18 by half a page, but that mention cannot be seen as an identification of the version in which the Bible verse in question is cited. Moreover, that PG edition does not allow the reader to find out how the text of Procopius actually looks like, since at column 988 it does not contain the text of the epitome any more: see Petit, La chaîne 1 (see note 9), xxxiii-xxxv.

20 In the present author's view, this methodological issue has to be taken into consideration by scholars who prepare a critical edition of Hexaplaric readings. He believes it to be necessary to reflect upon the sense and nonsense of distinguishing between (a) readings that genuinely enable the editor to identify and edit them as Hexaplaric ones (in other words: readings that can be used for textual reconstruction) and (b) readings that are indirectly useful by reflecting the reception of those Hexaplaric readings (in other words, readings that shed light on the textual history). Moreover, he believes that sources that offered readings of type (b) should not be left unmentioned. This belief is not that strange, since for the witnesses to the Lxx text, sources that offer type (b) readings are in fact often mentioned. The first apparatus to the Göttingen editions abounds in manuscript readings and patristic quotations that only reflect the reception of the text and which the editor surely never really took into consideration as being edited as the Old Greek text. In other words, Göttingen's first apparatus features readings that offer data for 'textual reconstruction' as well as others that only testify to 'textual history'. The presence of the latter group of readings is never questioned, although they do not add to the editing process of the text but only to our knowledge of its reception. Nevertheless, the Hexaplaric reading quoted by Apollinaris for Gen 2:23 illustrates that in the second apparatus only readings that contribute to 'textual reconstruction' tend to be mentioned, whereas those that shed further light on 'textual history' are ignored. The present author calls this course of action into question, since it hinders a correct appreciation of patristic and Byzantine reception of the Hexaplaric readings (as the example of Apollinaris shows). Moreover, it is often not clear (as in the case of Apollinaris' example of Gen 49:13/ Deut $33: 18$ ) on which basis an editor decides which source is chosen to be mentioned in the apparatus and which is not. This is risky, since sometimes sources that are silently 
above, a consistent criterion that would have been used by previous editors for having left out Apollinaris' testimony cannot be identified. In the present author's opinion, forthcoming critical editions of Hexaplaric readings should try to mention the information offered by Apollinaris (especially in the second case), or at least explain why his evidence is chosen not to be included. ${ }^{21}$ Be that as it may, it is clear that in both cases, Apollinaris is a very useful and richer source of Hexaplaric readings than present-day Hexaplaric editions show. More nuanced treatment of the cases mentioned above by Hexaplaric editors would have contributed to the appreciation of Apollinaris as an author who had access to Hexaplaric readings.

Stepping away from the catenae on Genesis and moving toward another part of the same catenae on the Octateuch, namely the part on Leviticus, an additional remark can be made. The catenae on Leviticus have not yet been edited critically, but R. Devreesse already surveyed scholia he believed to belong to Apollinaris. His study is to be handled with care since its author did not consult the entire manuscript basis. In that survey, Devreesse drew attention to an $\alpha^{\prime}$ and $\sigma^{\prime}$ reading that Apollinaris provided for Lev 16:10.22 Both readings were noticed by Field, who included them

considered to witness to 'textual history' and are therefore ignored, in fact should be looked upon as interesting sources for 'textual reconstruction' and consequently deserve to be mentioned in an edition of Hexaplaric readings. This can be illustrated by another example. In their editions of Hexaplaric fragments of Exodus, neither Field nor Wevers and Quast included the many readings Photius provided in his Amphilochia. This is understandable: throughout this work and especially when making text-critical observations and providing Hexaplaric readings, Photius relied to great extent upon Theodoret of Cyrrhus' questions on the Octateuch (CPG 6200). Nevertheless, this is not the case for the $\sigma^{\prime}$ reading of loc. 7:24 Photius quoted in Amphilochia 40 (in which he also mentioned $\alpha^{\prime}$ and $\theta^{\prime}$, yet without citing their precise readings): for this verse Theodoret did not quote any Hexaplaric readings. The $\sigma$ ' reading was already known to previous editors of Hexaplaric readings of Exodus: see Field, Origenis Hexaplorum (see note 14), ad loc., and John W. Wevers and Udo Quast, eds., Exodus (vol. 2,1 of Septuaginta: Vetus Testamentum Graecum Auctoritate Academiae Litterarum Gottingensis editum; Göttingen, 1991), ad Exod 7:24 app. 2. None of them mentioning Photius, they listed the Syro-Hexapla as well as the margins of the following LXX and catena manuscripts as sources: Ra 85 (10th century); Ra 135 (10th century); Ra 344 (10th century); Ra 57 (11th century); Ra 413 (12th century). One notices that Photius († ca. 894) is not mentioned, although his testimony provides a variant reading that cannot be found elsewhere and, more importantly, he is the earliest Greek source to have provided this reading.

21 This observation is not limited to the cases of Apollinaris that are discussed here. Other examples that illustrate the necessity to look into this methodological issue are manifold. For example, why is the evidence offered by Gregory of Nyssa, who referred to the $\sigma$ ' reading of Ps 9:17 (Gregory of Nyssa, In inscriptiones Psalmorum 2,10 [ed. R. Reynard; SC 466; 2002], 188,1-16, 190,17-36) and also quoted Gen 1:2a in the versions of $\alpha$, $\sigma^{\prime}$ and $\theta^{\prime}$ and 1:1a in that of $\alpha^{\prime}$ (Apologia in Hexaemeron), ignored by Field (Origenis Hexaplorum [see note 14], ad loc.) as well as Wevers (Genesis [see note 15], ad loc.)?

22 Devreesse, Les anciens commentateurs grecs de l'Octateuque et des Rois (see note 13), 128; for the fragment see p. 135, edited on the basis of the so-called catena Nicephori or catena Lipsiensis (on which, see Petit, La chaîne 1 [see note 9], xxxiv-xxxv) and two manuscripts of the type III catena, namely $\mathrm{Ra} 73$ and $\mathrm{Ra} 550$. 
into his edition and identified Apollinaris as the source. ${ }^{23}$ In the second apparatus to their Septuagint edition, Wevers and Quast not only included both readings but also consulted a manuscript basis that is much broader than the previous one. ${ }^{24}$ Nevertheless, they did not identify Apollinaris as (one of) the patristic source(s) to have provided these readings: they limited themselves to indicating that the Hexaplaric data in question can be found in a patristic scholion that is present in the catena manuscripts they referred to.

Neither of the references provided by Field and offered by Wevers and Quast is satisfying. Undoubtedly, it would have been better if both Göttingen editors would have identified the patristic source of the Hexaplaric readings that is preserved in the catenae. This would have provided scholars with a more useful tool to study Christian reception of the Hexapla. ${ }^{25}$ In the present formulation, their entry does not allow the reader to assess the extent to which the Father in question knew and transmitted Hexaplaric readings. This is a shortcoming in the editors' treatment of Apollinaris as a source of Hexaplaric readings, but this shortcoming is completely understandable: ${ }^{26}$ if no critical edition is available of the catenae whose scholia are sources of Hexaplaric readings, it is hard for the editors of those readings to identify the Father that offered them. After all, also Field's reference does not satisfy. Since he did not have a critically edited or studied catena at hand nor had access to several manuscripts of that catena, his identification of Apollinaris as the patristic source of the Hexaplaric reading is not fully trustworthy, not even when it is supported by Devreesse's identical identification.

23 See Field, Origenis Hexaplorum (see note 14), ad Lev 16:8 (pro 16:10). He had accessed the reading through the catena Nicephori, which for this fragment relies on the single manuscript Ra 313.

24 See John W. Wevers and Udo Quast, eds., Leviticus (vol 2,2 of Septuaginta: Vetus Testamentum Graecum Auctoritate Academiae Scientiarum Gottingensis editum; Göttingen, 1986), ad loc. app. 2. Their reference to C"comm includes the manuscript consulted by Field, since Ra 313 is a member of the cII subgroup.

25 Evidently, finding unknown materials of $\alpha^{\prime}, \sigma^{\prime}$ and $\theta^{\prime}$ remains a priority in Hexaplaric studies. In addition, however, the present author believes it is time to put more effort into understanding how the data Origen had included into his Hexapla later circulated within Greek Christianity. This can only be done when patristic and Byzantine sources of Hexaplaric readings are identified and mapped out in detail.

26 Therefore the present comment is not intended as a reproach towards Wevers and Quast's second apparatus. Apart from the discussion at hand, however, there is a critical remark that can be made: their reference to C"comm cannot be correct. That group contains three manuscripts that are no catena witnesses but Lxx codices containing little to no marginal notes ( $\mathrm{Ra} 16, \mathrm{Ra} 46$ and $\mathrm{Ra} 131$ ) - four if one includes $\mathrm{Ra} 320$, which is also no catena manuscript but which contains many marginalia. Those manuscripts cannot have contained the catena fragment in which the Hexaplaric readings are provided. This remark shows that classifications of manuscripts that are made for critical editions of LXX are not necessarily useful for editions of Hexaplaric readings and vice versa. This observation is to be kept in mind by future editors of Hexaplaric readings. 
There is only one way in which these flaws can be remedied, and that is by making sure that a critical edition of the catena in question is available to the editor of Hexaplaric readings. If this is not the case, he or she should make sure to have access to at least several manuscripts of that catena. In an ideal world, the editor would also indicate to which Father(s), if any at all, the catena scholion is attributed when a Hexaplaric reading is offered. Only then we can move on to identifying Greek-Christian reception of the Hexapla. In sum, these cases show that preparing critical editions of catenae is in the interest of Hexaplaric studies: it is an important task for all scholars in that field of research.

\section{Catenae on Psalms: Apollinaris unnoticed as a Hexaplaric source (by lack of a critical edition)}

Without critical editions of catenae one does not only run the evident risk of not noticing many unknown Hexaplaric readings but also of failing to correctly assess which Fathers are rich sources for Hexaplaric data and which ones are not. This should be avoided by all means, since mapping out the Hexapla's Christian reception is certainly one of the topics future Hexaplaric studies should address.

An obvious example of how critical studies and editions of catenae are necessary in order to appreciate how rich or poor a Hexaplaric source a certain Father is, is that of Apollinaris' fragments on Psalms (CPG 3681). Field's edition of Hexaplaric readings of that Bible book, which is still the standard one up to the present, ${ }^{27}$ gives the reader the impression that Apollinaris was either unaware of or not interested in the versions of $\alpha$, $\sigma^{\prime}$ and $\theta^{\prime}$ of the Psalter. Throughout Field's notes, which contain brief (and often not very clear) references to the sources of the Hexaplaric readings

27 Of course to be supplemented by other editions that have appeared since them, the most important of them being (in addition to the writings by Gilles Dorival mentioned elsewhere in the present article [see notes 7 and 29]): Patres antenicani (vol. 3 of Analecta Sacra Spicilegio Solesmensi parata; ed. J. B. Pitra; Venice, 1883), 557-560; Charles Taylor, ed., Hebrew-Greek Cairo Genizah Palimpsests from the Taylor-Schechter Collection: Including a Fragment of the Twenty-Second Psalm According to Origen's Hexapla (Cambridge, 1900); Giovanni Mercati, ed., Psalterii Hexapli reliquiae vol. 1: Codex rescriptus Bybliothecae Ambrosianae O 39 Sup. phototypice expressus et transcriptus (Codices ex ecclesiasticis Italiae bybliothecis selecti phototypice expressi 8; Città del Vaticano, 1958); Adrian Schenker, Hexaplarische Psalmenbruchstücke: Die hexaplarischen Psalmenfragmente der Handschriften Vaticanus graecus 752 und Canonicianus graecus 62 (Orbis biblicus et orientalis 8; Freiburg, 1975); Adrian Schenker, Psalmen in den Hexapla: Erste kritische und vollständige Ausgabe der hexaplarischen Fragmente auf dem Rande der Handschrift Ottobianus graecus zu den Ps 24-32 (Studi e Testi 295; Città del Vaticano, 1982); Giovanni Mercati, "I nomi alle versioni nuove nelle omilie sui Salmi di S. Giovanni Crisostomo," in idem, Alla ricerca dei nomi degli "altri" traduttori nelle omilie sui Salmi di S. Giovanni Crisostomo e variazioni su alcune catene del Salterio (Studi e Testi 158; Città del Vaticano, 1952). 
that were edited by him, Apollinaris' name is mentioned only seldom. This is largely due to the fact that Field did not have the opportunity to consult any critical edition of any catena on Psalms. ${ }^{28}$ If he would have been able to do so, his notes would have looked differently and Apollinaris would have occupied a more prominent position. This is nicely illustrated by Marguerite Harl and Gilles Dorival's critical edition of the Palestinian catena on Ps 118, which appeared almost a century after Field's collection of Hexaplaric readings was published: this edition showed that Apollinaris in fact is a valuable source of Hexaplaric readings of Psalms. ${ }^{29}$

Having identified six Hexaplaric readings in four scholia that belong to Apollinaris, Dorival listed him as the second richest author in this part of the Palestinian catena when it comes to Hexaplaric readings. ${ }^{30}$ This image was soon enforced when three years later Mühlenberg's critical edition of fragments attributed to Apollinaris in the catenae on the entire Psalter (so not just Ps 118) appeared. ${ }^{31}$ A quick glance through these scholia illustrates the considerable amount of Hexaplaric readings that are offered by Apollinaris. ${ }^{32}$ Guided by the index prepared by Mühlenberg, the present author counted 20 readings of Psalms offered by Apollinaris. ${ }^{33}$ When

28 To a large extent, Field relied on the references to manuscripts of catenae on Psalms offered by B. de Montfaucon in his edition of Hexaplaric readings: Hexaplorum Origenis quae supersunt, multis partibus auctiora, quam a Flaminio Nobilio et Joanne Drusio edita fuerint: Ex manuscriptis et ex libris editis eruit et notis illustravit (ed. B. de Montfaucon; vol. 1; Paris, 1713), 472-656. Many of those references are very vague; they were faithfully copied but not always understood by Field. How his reliance upon de Montfaucon's edition also affected the way in which Apollinaris was integrated into Field's edition of Psalms can be illustrated with the example of Ra 1133, a tenth-century catena manuscript of type III that was one of de Montfaucon's sources (see vol. 1, 472 of his edition: Codex Reg., $X$ saeculi, num. 1878). This manuscript is an important witness for finding scholia of Apollinaris (Mühlenberg, Psalmenkommentare 1 [see note 10], xxvi-xxvii), many of which contain Hexaplaric readings. Through de Montfaucon's edition, Field included references to such readings offered by Apollinaris in that catena type, but limited himself to referring to them as unus Regius or the like, without mentioning Apollinaris' name.

29 Marguerite Harl and Gilles Dorival, eds., La chaîne palestinienne sur le Psaume 118 (Origène, Eusèbe, Didyme, Apollinaire, Athanase, Théodoret): Introduction, texte grec critique, traduction et notes (2 vols.; SC 189-190; Paris, 1972).

30 Harl and Dorival, La chaine 1 (see note 29), 120. All of those six readings are included in the enumerations given below (notes 34-39).

31 Mühlenberg, Psalmenkommentare 1 (see note 10), 3-118. Useful as this edition may be, one should remark with D. Hagedorn (in his review of Mühlenberg's edition: Dieter Hagedorn, review of E. Mühlenberg, ed., Psalmenkommentare aus der Katenenüberlieferung, JbAC 20 [1977]: 198-202) that editing a catena as a collection is to be preferred over singling out the scholia identified as or ascribed to one particular Father in that catena.

32 Some of them could already be found in the scholia of Apollinaris that were surveyed (sometimes incorrectly) by Robert Devreesse, Les anciens commentateurs grecs des Psaumes (Studi e Testi 264; Città del Vaticano, 1970), 211-222.

33 The index prepared by Mühlenberg (Psalmenkommentare 2 [see note 10], 390) is not very practical to scholars who are investigating Hexaplaric readings of Psalms, since it only identifies the page and line numbers of his edition and not the biblical verses. Therefore the present article enumerates them with an identification of the Psalm verse. In addition to those 20 readings, Apollinaris also provided a rather vague reference to 
comparing them with Field's edition, one notices that 14 of them were already known to him, either in that identical wording ${ }^{34}$ or in a variant one. ${ }^{35}$ Of those 14 readings, however, only one was identified to Field as originating from Apollinaris. ${ }^{36}$

This overview undeniably shows that Apollinaris is a valuable source of Hexaplaric readings for the book of Psalms, although Field's edition does not indicate this. This observation is corroborated by the fact that, next to the 14 Hexaplaric readings that were already known to Field, Apollinaris' scholia in the catenae on Psalms yield 6 other readings of that biblical book that are new: either they are completely unknown, ${ }^{37}$ or they shed new light on the already known Hexaplaric data, by constituting Greek evidence in addition to a Syriac reading ${ }^{38}$ or by offering an unknown attribution. ${ }^{39}$ In addition, Apollinaris provided four readings of Ezekiel (20:47 $\alpha^{\prime}$ and o' and 21:3 $\alpha$ ' and o') in his explanation of Ps 78:1-3 (PTS 15, 51,2-6 Mühlenberg). None of them have been noticed by editors of Hexaplaric readings of Ezekiel, ${ }^{40}$ probably because they did not consult the catenae on Psalms (see below).

This brief consultation of some of Apollinaris' fragments on Psalms, preserved in the catenae, proves that Apollinaris was indeed very aware of and interested in the Hexaplaric versions of that book. This was not shown by Field's edition of those readings, since he did not have access to critically edited catenae and provided only vague references to catena manuscripts. This observation ties in with the conclusion formulated at the end of the paper's previous section and underlines the necessity of continuing to critically edit catenae. But Apollinaris' mention of Hexaplaric readings of Ezekiel in those scholia on Psalms shows that the availability

or paraphrase of a $\sigma^{\prime}$ reading of Ps 109:3-4 (PTS 15, 80,1 Mühlenberg), as well as one reading of oi $\lambda^{\prime}$ for which it is hard to identify the verse to which it belongs $(60,15 \mathrm{M}$.). The number of 20 readings does not include the $\sigma^{\prime}$ reading for Ps 73:15 (already known to Field), which is also edited by Mühlenberg (43,9 M.), but whose source is not Apollinaris.

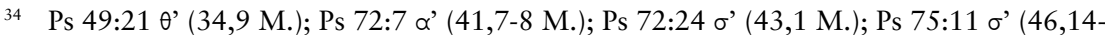

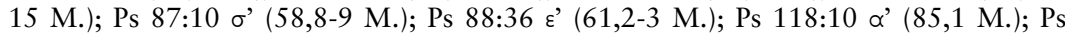
118:122 a' $\theta^{\prime}(93,10-11$ M.); Ps 131:15 o' (46,3 M.; also assigned by Apollinaris to हैтвроS in 100,12 M.).

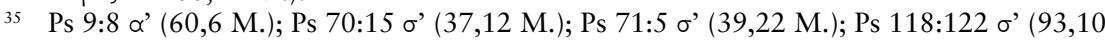
M.); Ps $140: 10 \sigma^{\prime}(111,18$ M.).

36 Ps 88:36 ₹'. Field did not refer to a catena scholion in all of the fourteen cases mentioned above, but this does not disprove the present argument: even if he would have encountered the reading in a catena scholion, he would not necessarily have referred to it if he had already mentioned another Greek source (such as a LXX manuscript or a previous edition of Hexaplaric readings).

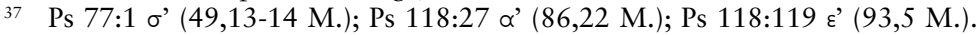

38 Ps 118:27 $\sigma^{\prime}(86,22-23$ M.).

39 Ps 78:1 $\theta^{\prime}\left(50,10\right.$ M.); Ps 110:5 $\alpha^{\prime} \sigma^{\prime}$ (46,4 M.).

40 Field, Origenis Hexaplorum (see note 14) and Joseph Ziegler, ed., Ezechiel (vol. 16,1 of Septuaginta: Vetus Testamentum Graecum Auctoritate Academiae Litterarum Gottingensis editum; with a postscript by D. Fraenkel; Göttingen, 2006). 
of critical editions of catenae is not enough: editors of Hexaplaric readings are also required to consult them. Due to editors not having turned to catena manuscripts, Apollinaris' familiarity with Hexaplaric readings of another biblical book has once again gone by unnoticed.

\section{Catenae on the Pauline Epistles: Apollinaris unnoticed as a Hexaplaric source (due to catenae not being consulted)}

At present, consultation of all kinds of catenae (and other Greek texts, of course) is much facilitated by the availability of modern reference works and of the Thesaurus linguae graecae and other search engines, which previous editors of Hexaplaric readings did not always have at their disposal. ${ }^{41}$ As a consequence, today readings that were not noticed by a previous editor can be found even in catenae that were already available in a critical edition at the moment when that previous editor of Hexaplaric readings prepared his edition.

Such a situation has also occurred with respect to Hexaplaric readings offered by Apollinaris in his commentary on Romans (CPG 3694). This commentary is lost apart from fragments preserved in the catenae on the Pauline Epistles. Parts of some of those catenae were already edited by Staab in 1933:42 this edition also included fragments of Apollinaris' commentary on Romans. In those scholia, Apollinaris offered some Hexaplaric readings of Isaiah and one of Psalms. The reason why he did this can be explained on the basis of an example.

A part of Isa 29:10 is echoed in Rom 11:8:

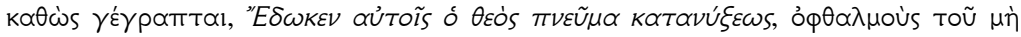

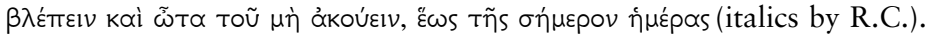

Guided by this echo, Apollinaris cited the words of the prophet in his explanation of the Pauline verse:

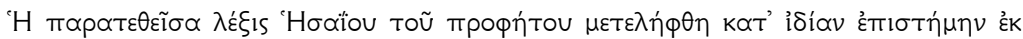

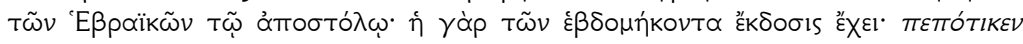

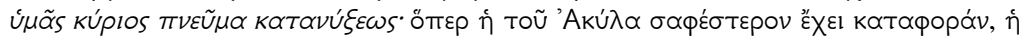

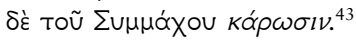

Apollinaris quoted those words of Isa 29:10 that are echoed in Rom

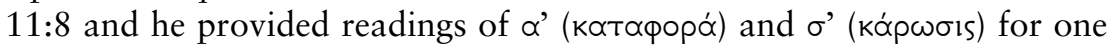

41 See the remark made above (note 5).

42 See Staab, Pauluskommentare (see note 11). Staab edited fragments of some individual authors preserved in this corpus of catenae. For a critical remark on this approach, see note 31 .

43 Staab, Pauluskommentare (see note 11), 72,15-19 (italics by R. Ceulemans). 


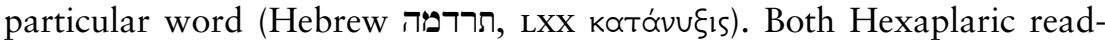
ings were already known to Field, who copied them from the Hexaplaric apparatus to the 1587 Sixtina edition ${ }^{44}$ and found corroboration of the $\alpha$ ' reading in Jerome's commentary (CPL 584)..$^{45}$ Both readings, namely

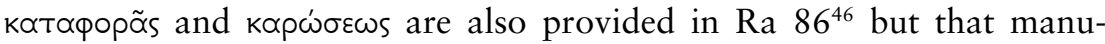

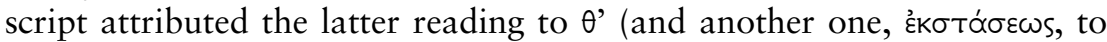
$\sigma^{\prime}$ whereas in fact that is the $\theta^{\prime}$ reading). Ignoring this attribution of $\mathrm{Ra}$

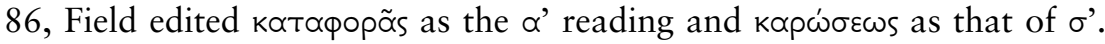
The same was done by Joseph Ziegler in the Hexaplaric apparatus to his Göttingen edition: he added the commentaries on Isaiah by Eusebius of Caesarea (CPG 3468) and Theodoret of Cyrrhus (CPG 6204) as additional witnesses to both readings. ${ }^{47}$

Neither editor noticed the evidence offered by Apollinaris. They should have done, however, since it is definitely trustworthy: although he offered both readings in the accusative case, Apollinaris' testimony is in clear agreement with those of Jerome (only for $\alpha$ '), Eusebius and Theodoret. Moreover, this fragment is an additional confirmation of Field's and Ziegler's decision to ignore $\mathrm{Ra} 86$ 's faulty attribution of the $\sigma$ ' reading.

These readings of Isa 29:10 are not the only ones Apollinaris offered in his commentary on Romans. Throughout the fragments edited by Staab, readings of $\alpha$ ' can be found of Isa 8:13b-14a (in Apollinaris' comment on Rom 9:33); Isa 65:15-16a (in his exegesis of Rom 11:11); Ps 39:6 (in his fragment on Rom 11:33-36). All of them have escaped the attention of

44 Vetus Testamentum iuxta Septuaginta ex auctoritate Sixti V. Pont. Max. editum (Rome, 1587). Although the Hexaplaric data for this edition were collected by Pierre Morin (Petrus Morinus), Field referred to it as Nobil[ius]. Flaminius Nobilius was the person who was responsible for the Hexaplaric apparatus to the bilingual (Greek and Latin) edition of Sixtina that appeared one year after the original one: Vetus Testamentum secundum LXX Latine redditum et ex autoritate Sixti V. Pont. Max. editum: Additus est index dictionum et loquutionum hebraicarum, graecarum, latinarum, quarum observatio visa est non inutilis future (Rome, 1588). The Hexaplaric apparatus in the latter edition is almost completely identical to that of Morinus. Field, although having consulted the original 1587 edition, systematically and erroneously used the name of Nobilius (instead of that of Morinus) to refer to it. The main reason for this confusion is the fact that Morinus' name is nowhere mentioned in the 1587 Sixtina editon, whereas Nobilius is identified as the Hexaplaric editor of the bilingual 1588 edition. A more extensive discussion of this topic, with references to secondary literature, can be found in Reinhart Ceulemans, A Critical Edition of the Hexaplaric Fragments of the Book of Canticles, with Emphasis on their Reception in Greek Christian Exegesis (Ph.D. diss., Katholieke Universiteit Leuven, 2009), 18-27.

45 Field, Origenis Hexaplorum (see note 14), ad loc.

46 Together with Ra 86, Field also referred to " 88 ": this is not Ra 88, but a negligible copy of Ra 86 made by Leo Allatius († 1669). See Rahlfs, Verzeichnis (see note 1), 280 n. 1 and Joseph Ziegler, ed., Isaias (vol. 14 of Septuaginta: Vetus Testamentum Graecum Auctoritate Academiae Litterarum Gottingensis editum; 2d revised ed.; Göttingen, 1967), 36-60.

47 Ziegler, Isaias (see note 46), ad loc. app. 2. 
Field and (in the case of the Isaiah verses) Ziegler. ${ }^{48}$ Nevertheless, Ziegler's edition (1939) appeared several years after the fragments in question of Apollinaris had been edited critically by Staab (1933). Therefore, in these cases the fact that Apollinaris' testimony was not recorded in the editions of Hexaplaric readings now available, cannot be explained by the lack of a critical edition of the catenae in question at that time. Instead, it results from the fact that the catenae were not consulted by the editors of Hexaplaric readings.

The reason why editors of Hexaplaric readings did not consult New Testament catenae is quite understandable. Nevertheless, the example discussed above shows that consultation of those exegetical chains is quite useful and that in fact it is not that odd to encounter Hexaplaric readings in patristic commentaries and catenae on New Testament books. Like many modern scholars, ${ }^{49}$ Greek authors sometimes observed that a certain New Testament citation of an Old Testament passage is closer to the version of $\alpha$ ' (or another one) than to that of the Lxx. Apollinaris did so not only in his comment (discussed above) on Rom 11:8 but also in his exegesis of Rom 9:33: in both cases this remark resulted in the citation of at least one Hexaplaric reading. Obviously, Apollinaris is not the only Father to have made such observations: several other examples can be found in patristic and Byzantine exegesis of New Testament passages, ${ }^{50}$ not all of them having been noticed by editors of Hexaplaric readings. ${ }^{51}$ Therefore,

48 For all of these fragments, the author relies upon the edition and attribution to Apollinaris offered by Staab. It should be kept in mind, however, that for some of them, both edition and attribution rely upon a single manuscript (Vaticanus gr. $762=$ CPG C 160) and that in one case (i.e., the fragment on Rom 9:33) the attribution of that manuscript to Apollinaris is contradicted by another witness (Monacensis gr. $412=$ CPG C 161), which attributes the fragment in question to Gennadius of Constantinople. (It is under that name and on the basis of that manuscript that this fragment can be found in Catena in Sancti Pauli Epistolam ad Romanos ad fidem codd. mss. [vol. 4 of Catenae Graecorum Patrum in Novum Testamentum; ed. J. A. Cramer; Oxford, 1844; repr., Hildesheim, 1967], 367.) This caveat notwithstanding, Staab's judgment is followed in all cases, in accordance with the methodological remark made above (note 6).

49 Research on this topic tends to be carried out by New Testament specialists (rather than by LXx scholars) and has resulted in a bibliography that is far too extensive to be surveyed here. For a very recent example, in which one of the specific cases of Apollinaris mentioned above was noticed, see Dietrich-Alex Koch, "The Quotations of Isaiah 8,14 and 28,16 in Romans 9,33 and 1Peter 2,6.8 as Test Case for Old Testament Quotations in the New Testament," ZNW 201 (2010): 223-240.

50 A fine example (and one that, in contrast to the examples of Apollinaris, was known to Ziegler) is that of the link Origen (Philoc. 9,2) perceived between the quotation of Isa 28:11 in 1 Cor 14:21 and the version of $\alpha$ '. In pointing out that similarity, he used the

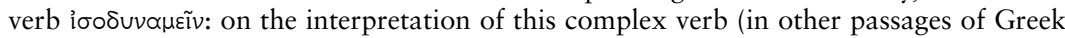
literature), see Dries De Crom, "Translation Equivalence in the Prologue to Greek Ben Sirach," in XIII Congress of the International Organization for Septuagint and Cognate Studies: Ljubljana 2007 (ed. M. K. H. Peters; Society of Biblical Literature Septuagint and Cognate Studies Series 55; Atlanta, 2008), 97-109.

51 For example: in his comment on Rom 10:21, a New Testament verse in which Isa 65:2 is quoted, Theodoret (Interpretatio epsitulae ad Romanos [PG 82:169c]) offered an $\alpha$ ' $\sigma^{\prime}$ 
future editors are advised to pay more attention to this corpus. More in general, one should look into all kinds of catenae, both on the Old and the New Testament, even if they do not treat the particular biblical book Hexaplaric readings are edited for. This can easily be done by means of the Thesaurus Linguae Graecae and other ways of research. After all, a lack of this kind of exploration not only explains how the readings of Psalms and Isaiah offered by Apollinaris in his commentary on Romans have gone by unnoticed, but also why the readings of Ezekiel that can be found in the remaining fragments of Psalms (see above) were not recorded.

Moreover, these examples once again show that various Hexaplaric readings offered by Apollinaris have escaped scholarly attention and that his qualities as a source of such readings have not been appreciated correctly.

\section{On Apollinaris' Hexaplaric source(s)}

The previous pages have shown that Apollinaris is a richer source of readings of $\alpha^{\prime}, \sigma^{\prime}$ and $\theta^{\prime}$ than currently available editions of Hexaplaric readings as well as present-day studies of Apollinaris' writings may cause to think. Although the editions of Ezekiel and Isaiah by Field and Ziegler do not list him in their prefaces as one of the sources of Hexaplaric readings nor ever mention his name in their notes (Field) or Hexaplaric apparatus (Ziegler), Apollinaris in fact offered various Hexaplaric readings of those books. Moreover, the previous sections have shown that he knew more readings of Genesis, Deuteronomy and Psalms than can be suspected on the basis of currently available editions. As stated in the present paper's opening paragraph, Apollinaris' interest in the biblical text and its various versions is not so surprising, as it can be explained by the classical philological training he received and his Antiochene exegetical approach. ${ }^{52}$ Moreover, the fact that he taught exegesis to Jerome characterizes his reputation in this area.

These observations raise the question what can be said about the Hexaplaric source(s) that was/were available to Apollinaris. Three possible scenarios emerge: (1) Apollinaris gleaned his readings of $\alpha^{\prime}, \sigma^{\prime}$ and $\theta^{\prime}$ directly from the original synopsis of the Hexapla; (2) he had indirect access to the Hexapla through a (partial) copy, a glossed Lxx text or another kind

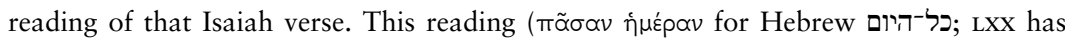

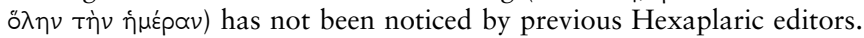

52 This philological and text-critical interest of Apollinaris is not limited to quotations of $\alpha^{\prime}, \sigma^{\prime}$ and $\theta^{\prime}$. For example, Apollinaris is one of the rather few Greek authors to have quoted readings from ó súpos. See Field, Origenis Hexaplorum 1 (see note 14), lxxvii, confirmed by Robert B. ter Haar Romeny, A Syrian in Greek Dress: The Use of Greek, Hebrew, and Syriac Biblical Texts in Eusebius of Emesa's Commentary on Genesis (Traditio Exegetica Graeca 6; Leuven, 1997), 72-85. 
of abbreviated edition that circulated in the Antiochene school; (3) he did not have access to the Hexapla but only relied on readings provided by patristic predecessors. ${ }^{53}$ Although it is impossible to settle the question of Apollinaris' source(s) in a decisive way, the formulation of some observations may prove useful.

The third option does not seem very probable. The overview of readings mentioned in the present article, which is only a very incomplete one, ${ }^{54}$ shows that Apollinaris' source(s) allowed him to consult Hexaplaric readings of Genesis, Leviticus, Deuteronomy, Psalms, Isaiah and Ezekiel. This list of biblical books is certainly not complete, since other catenae have preserved readings of other books offered by Apollinaris, such as the Song of Songs..$^{55}$ In addition, some non-catena sources show that Apollinaris knew Hexaplaric readings of other books, such as Ecclesiastes ${ }^{56}$ and Zechariah. ${ }^{57}$ This wide range of books for which he quoted Hexaplaric readings throughout his writings ${ }^{58}$ argues against the hypothesis that he gleaned all of them from the exegesis of his predecessors. Admittedly, for Psalms as well as the Octateuch, Apollinaris must have had a considerable collection of commentaries by contemporary and earlier Antiochene

53 A fourth scenario that could be theoretically possible, namely that Apollinaris accessed the versions of $\alpha^{\prime}, \sigma^{\prime}$ and $\theta^{\prime}$ through Jewish contacts, is unlikely. He did not provide any clues that point into this direction. The only quotation in which he mentioned Jews and a Greek Bible version in one and the same breath, is a passage in his comment on Rom 11:11 (mentioned above): after having cited a part of Isa 65:15-16a in the version of

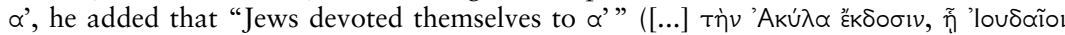

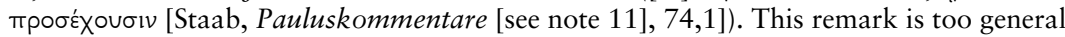
to allow for the assumption of any contacts with Jews regarding those versions. Moreover, the fact that he more than once provided readings of $\varepsilon^{\prime}$ (see notes 34 and 37 ) undeniably shows that his knowledge of that and other versions is to be traced back to the Hexapla (whether directly or indirectly).

54 One has to keep in mind that the present article focuses on data taken from some critically edited catenae only.

55 See note 8 .

56 In his commentary on Eccl 12:5 (CPL 583), Jerome quoted the $\sigma^{\prime}$ reading of that verse and mentioned that Apollinaris knew (and preferred) this reading. See Sandro Leanza, "Sulle fonti del Commentari all'Ecclesiaste di Girolamo," Annali di Storia dell'Esegi 3 (1986): (173-199) 174.

57 Gregory of Nyssa's refutation of Apollinaris' interpretation of Zech 13:7 shows that the latter knew an $\alpha$ ' reading of that verse. See Marguerite Harl, "La polémique de Grégoire de Nysse contre l'usage de Zacharie 13,7a par Apollinaire," in Grégoire de Nysse: la Bible dans la construction de son discours, Actes du Colloque de Paris, 9-10 février 2007 (ed. M. Cassin and H. Grelier; Collection des Études Augustiniennes, Série Antiquité 184; Paris, 2008), (89-99) 93-97.

58 Observe that the present study ignores the Metaphrasis Psalmorum (CPG 3700), which appears to contain (anonymously, of course) some Hexaplaric readings (its self-proclaimed adherence to the Lxx text notwithstanding) but which does not seem to have been written by Apollinaris. Cf. Joseph Golega, Der homerische Psalter: Studien über die dem Apolinarios von Laodikeia zugeschriebene Psalmenparaphrase (Studia Patristica et Byzantina 6; Ettal, 1960), 150-168. 
Fathers at his disposal. ${ }^{59}$ For e.g. Isaiah and the Song of Songs, however, this is not the case. ${ }^{60}$

Therefore, the observation that at least one of the Hexaplaric readings quoted by Apollinaris is paralleled in commentaries by Diodore of Tarsus (more or less a contemporary to him) and especially by Eusebius of Emesa (living some thirty years earlier) ${ }^{61}$ should be regarded as an argument, if at all, in favor of the second rather than the third scenario. The circulation of partial copies of the Hexapla or of Lxx manuscripts with Hexaplaric marginalia is quite probable for the Antiochene school. ${ }^{62}$ Reliance upon such a common Hexaplaric source offers a more reasonable explanation of parallels between Apollinaris' and other Antiochene authors' references of certain readings (i.e., more reasonable than the suspicion that Apollinaris merely relied upon previous commentaries). ${ }^{63}$ In other words, the second scenario as formulated above appears to be quite probable.

59 The Octateuch, especially, is a corpus regarding which Antiochene Fathers earlier than or contemporary to Apollinaris, such as Eusebius of Emesa (CPG 3532) or Diodore of Tarsus (CPG 3815), displayed notable interest in the various text versions. This topic received ample treatment in ter Haar Romeny, A Syrian in Greek Dress (see note 52). In his commentary on the Psalms (CPG 3818), on the other hand, Diodore included notably less Hexaplaric readings. See Jean-Marie Olivier, introduction to Commentarii in Psalmos, by Diodore (CChr.SG 6; Turnhout, 1980), (vii-cxxiii) xcix-c, and Jean-Noël Guinot, "La fortune des Hexaples d'Origène aux IVe et Ve siècles en milieu antiochien," in Origeniana Sexta: Origène et la Bible/Origen and the Bible, Actes du Colloquium Origenianum Sextum, Chantilly, 30 août-3 septembre 1993 (ed. G. Dorival et al.; Bibliotheca Ephemeridum Theologicarum Lovaniensium 118; Leuven, 1995), (215-225) 217-218.

60 Admittedly, the Suda (cf. Suidae Lexicon 2 [vol. 1,2 of Lexicographi Graeci recogniti

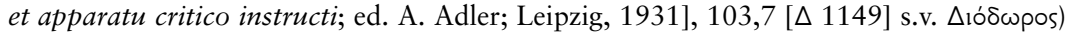
informs us that Diodore would have written a commentary on the Song of Songs. This remark, however, stands completely isolated and is not supported by any textual fragments. The commentaries on the same book by Theodore of Mopsuestia (CPG 3837) and Theodoret of Cyrrhus (CPG 6203) postdate Apollinaris.

61 Both authors knew the $\sigma$ ' reading of Gen 2:23 that was mentioned by Apollinaris (see above, note 13). For Eusebius (in Armenian translation) and Diodore, see ter Haar Romeny, A Syrian in Greek Dress (see note 52), 203 and Petit, Collectio (see note 9), 103-104 no. 100 respectively.

62 The way in which the Hexapla was received in Antioch is a complex matter that still requires further attention. Studies that enter into this topic tend to focus on one author only, such as those of Guinot on Theodoret of Cyrrhus (see his publications listed in Reinhart Ceulemans, "The Greek Christian Afterlife of the Minor Versions: The Possibilities of a Shift in Perspective," in Florilegium Lovaniense: Studies in Septuagint and Textual Criticism in Honour of Florentino García Martínez [ed. H. Ausloos, B. Lemmelijn and M. Vervenne; Bibliotheca Ephemeridum Theologicarum Lovaniensium 224; Leuven, 2008], [101-117] 113). Articles and the occasional book that try to reach a broader view on exegetical methods and sources in the Antiochene school, such as that of Robert C. Hill, Reading the Old Testament in Antioch (Bible in Ancient Christianity 5; Leiden 2005), pay only little attention to matters Hexaplaric. Consequently, a detailed study of the way in which the synopsis was received in Antioch, from Eusebius of Emesa up to Theodoret, would be most welcome. In such a study, also Apollinaris would have to be investigated carefully. Comparison of Hexaplaric materials preserved in the writings of several Antiochene authors could prove very useful in this regard.

63 Moreover, before focusing too much on such parallels between Apollinaris and other Antiochene authors, one also has to take a look at resemblances between Apollinaris 
The few scholars who in the past have looked at the question which Hexaplaric source Apollinaris could have accessed, are the above-mentioned editors of catenae on Psalms. Both of them, Dorival and Mühlenberg, favored the first of the three scenarios suggested above. The high amount of Hexaplaric readings he encountered in Apollinaris' fragments on Psalms lead Mühlenberg to conclude that "Apollinaris appears to have been one of the few [Greek authors, R.C.] to have used Origen's Hexapla." ${ }^{64}$ The scholar who wishes to subscribe wholeheartedly to this hypothesis, has to be warned that it may have been formulated somewhat too hastily. Seeing that a thorough study of Apollinaris' exegesis was lacking at that time (as it still is now), ${ }^{65}$ Mühlenberg limited himself in his edition to identifying quotations of and allusions to biblical versions only: parallels with patristic sources were ignored. ${ }^{66}$ Fully understandable though this editorial decision may be, ${ }^{67}$ it does create a distorted image, since it does not allow for a recognition of parallels between Apollinaris and other Fathers, which can be quite important when speculating on his Hexaplaric source (especially in view of what has been said on the previous page). This being said, Mühlenberg's suggestion does reach a considerable level of probability, since Apollinaris travelled a lot. ${ }^{68}$ Although he is not known

and other sources. For example, for Isa 65:15a (mentioned above), he provided the same Hexaplaric readings as $\mathrm{Ra} 86$ did (be it with other attributions).

64 Mühlenberg, Psalmenkommentare 1 (see note 10), xxxiii: "Apollinaris is offensichtlich einer der wenigen, die die Hexapla des Origenes benutzt haben."

65 Consequently, the motives Apollinaris might have had for quoting $\alpha^{\prime}, \sigma^{\prime}$ and $\theta^{\prime}$ or the role those readings play in his exegesis have never been investigated, with the exception of oblique remarks such as one of Dorival in the notes to his introduction of Apollinaris as a source of Hexaplaric readings in the Palestinian catena on Ps 118 (Dorival and Harl, La chaine 1 [see note 29], 120). He observed that Apollinaris quoted $\alpha^{\prime}, \sigma^{\prime}$ and $\theta^{\prime}$ in such a way that he seemed to be learning more from them than from Lxx. This attitude illustrates the liberties he took with respect to the Bible text of the Eastern Church. It may be added that a similar remark was made earlier by Jerome (Adversus Rufinum 2,34 [CChr.SL 79, 71-72 Lardet]).

66 Mühlenberg, Psalmenkommentare 1 (see note 10), xxxiii. Mühlenberg's own subsequent publications (such as "Apollinaris von Laodicea und die origenistische Tradition," ZNW 76 [1985]: 270-283 and "Zur exegetischen Methode des Apollinaris von Laodicea," in Christliche Exegese zwischen Nicaea und Chalcedon [ed. J. van Oort and U. Wickert; Kampen, 1992], 132-147) do not enter into philological aspects, let alone biblical textcritical ones, of Apollinaris' exegesis.

67 The decision is understandable, not only considering the lack of study of Apollinaris' exegesis but especially in view of the absence of critical editions of the remaining and vast corpus of catenae on Psalms.

68 He was born in Laodicea, worked in Antioch, participated in a synod in Nazianzus, may have passed through Chalcis (see Mühlenberg, Apollinaris [see note 2], 362-365). Fuller descriptions of Apollinaris' life are old but hitherto not replaced: Johannes Dräseke, Apollinarios von Laodicea: Sein Leben und seine Schriften, Nebst einem Anhang: Apollinarii Laodiceni quae supersunt dogmatica (TU 7,3,4; Leipzig, 1892), 3-80, and Hans Lietzmann, Apollinaris von Laodicea und seine Schule: Texte und Untersuchungen (vol. 1; Tübingen, 1904), 1-78. See also Ekkehard Mühlenberg, Apollinaris von Laodicea (Forschungen zur Kirchen- und Dogmengeschichte 23; Göttingen, 1969), 26-63. 
to have visited Caesarea, it is not impossible that he visited the library to consult the original Hexapla.

Perhaps, as for now, the most reasonable explanation is the conclusion reached by Dorival, namely that "Apollinaris could have visited the library of Caesarea on his voyages; either way, he was in contact with men who had frequented the library." ${ }^{69}$ This view, together with the second scenario discussed above, is the most prudent (if indecisive) one, in expectation of further research that could shed new light on this issue. In any case, the suggestions formulated by Mühlenberg and Dorival rest on the assumption that Apollinaris' interest in the versions of $\alpha^{\prime}, \sigma^{\prime}$ and $\theta^{\prime}$ was strong enough to actively look for readings of those versions. Obviously, that assumption ties in with the conclusion this article wishes to bring across, namely that Apollinaris is a richer source of Hexaplaric readings that commonly assumed. These observations urge this author to be included in studies of reception of the Hexapla in the Antiochene school. ${ }^{70}$

\section{Concluding remarks}

An investigation into some of the scholia of Apollinaris that have been transmitted in three critically edited catenae has underlined the importance of catenae for finding remains of the versions of $\alpha^{\prime}, \sigma^{\prime}$ and $\theta^{\prime}$. Moreover, it has shown that Apollinaris is a richer source of readings of those versions than currently available editions of them might hint at. There are several reasons for this lack of reference of Apollinaris' name among the witnesses to Hexaplaric readings recorded in the collection of Field or in the Hexaplaric apparatus to the Göttingen editions. Firstly, an evaluation of Hexaplaric readings offered by Apollinaris in the catenae of Genesis brought up a methodological issue with respect to editing Hexaplaric readings: to what extent should an editor mention witnesses to readings that are edited on the basis of other sources? The fact that the average editor (silently) tends to ignore those sources probably caused the absence of Apollinaris' name in present-day editions.

Other reasons that explain why this author's qualities as a Hexaplaric source have gone by unnoticed are much more obvious. The catenae of Psalms were not yet edited critically when Field prepared his edition, which

69 Dorival, "L'apport” (see note 7), 50 n. 1: "Apollinaire [a] pu la [= la Bibliothèque de Césarée, R.C.] visiter au cours de voyages; en tout cas, [il a] été en contact avec des hommes qui avaient fréquenté cette bibliothèque." A similar view was put forward by him earlier (but not with respect to Apollinaris in particular) when he observed that many Fathers (other than Origen and Eusebius of Caesarea) had been able to access the Hexapla in Caesarea and that glossed editions that were in circulation were also a possible source of Hexaplaric readings. See Harl and Dorival, La chaine 1 (see note 29), 119. Observe that Harl ("La polémique" [see note 57], 94) made a similar suggestion regarding the source through wich Apollinaris got to know the $\alpha$ ' reading of Zech 13:7.

70 See note 62. 
relies on only few manuscripts of that complex corpus and in which references to patristic fragments in those catenae are very vague. Consequently, the large amount of readings offered by Apollinaris in his fragments on Psalms was not recorded properly. Finally, some of the readings provided by Apollinaris were never noticed since they are to be looked for in catenae that comment upon a different biblical book than the one the Hexaplaric readings apply to. This was illustrated on the basis of various readings offered by Apollinaris in his commentary on Romans, preserved in the catenae on the Pauline Epistles. The latter observation illustrates that the Hexaplaric richness of catenae has not yet been appreciated enough.

The combination of all of those reasons resulted in a neglect of Apollinaris as a Hexaplaric source: the amount of readings of $\alpha^{\prime}, \sigma^{\prime}$ and $\theta^{\prime}$ he quoted is higher than one can assume on the basis of the apparatus of currently available editions of Hexaplaric readings. In other words, Apollinaris was very much aware of and interested in the Hexaplaric versions. The biblical text-critical interest and abilities of this author, whose controversial Christology has distracted scholarly occupation from his exegetical qualities, deserve to be studied in more depth. In particular, his access to the amount of Hexaplaric data he managed to cite proves an interesting topic to address. The observation that he was able to cite several readings of a wide range of biblical books argues in favor of a source that was not very distant from the original Hexapla. Such a conclusion is of much relevance to the question of how Origen's synopsis was received in Antioch.

\section{ZUSAMMENFASSUNG}

Der vorliegende Artikel sucht zu beweisen, dass die Fragmente der verlorengegangenen Kommentare des Apollinaris von Laodizea (ca. 315-391), die in den Katenen erhalten sind, eine Quelle für die hexaplarischen (dass heisst Aquila-, Symmachus- und Theodotion-) Lesarten sind, die reicher ist, als es der Apparat der modernen hexaplarischen Editionen vermuten lässt. Die Analyse einiger Katenen-Fragmente der Kommentare des Apollinaris zu Genesis, den Psalmen und dem Römerbrief, in denen er verschiedene Aquila- und Symmachus-Lesarten geboten hat, macht deutlich, warum sein Zeugnis nicht in der Edition von Field und in der Göttinger Reihe vermerkt wird. Die folgenden Ursachen lassen sich aufzeigen: (1) auf Grund (stillschweigender) editorischer Prinzipen hat man sich dafür entschieden, andere Zeugen als Apollinaris zu nennen; (2) in Ermangelung kritischer Editionen der Katenen wurde Apollinaris nicht immer als die Quelle der hexaplarischen Lesarten erkannt; (3) manche Lesarten sind schlichtweg nicht bemerkt worden, da die Katenen, in denen sie zu finden sind, nicht herangezogen wurden. Die Erkenntnis, dass Apollinaris ein wertvoller Zeuge der hexaplarischen Lesarten ist, macht ihn zu einem wichtigen Studienobjekt für das Nachleben der Hexapla in der antiochenischen Schule. 